811.163.41'243-057.875:81'271.1

811.163.41'367

811.163.41'366

https://doi.org/10.18485/sj.2018.23.1.34

БИЉАНА М. БАБИЪ

Универзитет у Новом Саду

Филозофски факултет
Оригинални научни рад

Примљен: 04. 01. 2018.

Прихваћен: 29. 01. 2018.

\title{
УНУТАРЈЕЗИЧКЕ ГРЕШКЕ У УПОТРЕБИ ОБЛИКА АКУЗАТИВА У СРПСКОМ ЈЕЗИКУ КАО СТРАНОМ
}

У раду се спроводи морфолошко-синтаксичка анализа употребе облика акузатива (уз глаголе) уместо других падежних форми, на корпусу формираном ексцерпцијом грађе из писмених састава студената (нивои знања А1 и А2). Циљеви анализе су: идентификација грешака, њихова систематизација према типовима, издвајање и опис унутарјезичких грешака, квантификативна и статистичка обрада, излагање резултата анализе према типовима грешака и према првом језику студената.

Анализа показује да је облик акузатива укупно 223 пута употребљен уместо других падежа, најчешће уместо номинатива (85 примера) и локатива (72), далеко ређе уместо датива (39) и генитива (24), и сасвим спорадично уместо инструментала (3). Од тога се најмање 176 грешака може објаснити као унутарјезичке: замене субјекатског номинатива, спацијалног локатива и датива. У употреби акузатива грешили су представници 12 језика.

Кључне речи: српски језик као страни, морфологија, синтакса, падежи, акузатив, анализа грешака.

1. Увод. Грешке у писаној језичкој продукцији страних студената утврђују се поређењем њихових исказа с оним језиком који студенти уче на курсевима српског језика као страног, тј. са стандардним српским језиком (нормативни

"biljanab@ff.uns.ac.rs 
приступ, Бугарски 1996: 156; Ellis ${ }^{4}$ 1996: 51), па се грешком сматра свако уочено одступање од српске стандарднојезичке норме. Одступања свој узрок могу имати у преносу навика и знања из првог језика студента (тј. у међујезичкој интерференцији), или у преносу навика и знања из самог језика који се учи, из циљног језика (тј. у унутарјезичкој интерференцији: „to је interferencija ranije naučenih elemenata na kasnije naučene elemente [ciljnog - napomena B.B.] jezika, kao i interferencija češće upotrebljavanih na one koji se ređe upotrebljavaju" (F. Juhász, наведено према Бурзан: 1984: 18; уп. и Ричардс ${ }^{2}$ 1975: 182)). Ова друга одступања стога се називају унутарјезичким грешкама и дефинишу као грешке настале под утицајем самог језика који се учи (Ричардс $\left.{ }^{2} 1975: 173\right)$.

У теорији и пракси анализе грешака, поред појма грешке постоји и појам омашке. Разлика између њих, према С.П. Кордеру (S.P. Corder), могла би се - у најкраћем - објаснити на следећи начин. Грешкама (errors) сматрају се систематске грешке, оне које откривају учениково досадашње знање језика (или прелазну компетенцију), па се називају и грешкама компетенције или грешкама језичког знања. Омашке (mistakes) јесу несистематске грешке, оне настају случајно (као последица умора или узбуђења, на пример), па се називају и грешкама перформансе, и немају значаја за процес учења језика (Кордер $\left.{ }^{2} 1975 a: 25\right)$. И поред тога што С.П. Кордер омашке сматра безначајним за процес учења, анализа која следи обухвата све забележене неправилне облике акузатива, не делећи их на грешке и омашке. Грешкама се тако сматрају и омашке, а њихова разлика у односу на ове прве успоставља се на основу квантификативних података.

Анализом која следи обухваћене су грешке у употреби облика акузатива именица (уз предикацију) у српском језику као страном, на нивоима знања језика A1 и А2. Корпус је формиран ексцерпцијом грешака из писмених састава студената који су интензивни курс српског језика - једносеместрални или двосеместрални - похађали у Центру за српски језик као страни на Филозофском факултету у Новом Саду. Прегледана су укупно 503 састава, и ексцерпиране 223 грешке.

Циљеви анализе су идентификација грешака, издвајање унутарјезичких грешака, њихова систематизација према типовима, опис унутарјезичких грешака, као и узрока њиховог настанка (тамо где је то могуће), квантификативна и статистичка обрада, потом излагање резултата анализе према типовима грешака и према првом језику студената.

Анализа грешака у употреби падежних облика спроводи се на морфолошко-синтаксичко-семантичком нивоу, из два разлога: падеж је у српском језику истовремено и морфолошка и синтаксичко-семантичка категорија (Антонић 2005: 119-120), па се према методичкој концепцији уџбеника Научимо српски 
- Let's Learn Serbian $1^{1}$,istovremeno [...] padež uvodi kao morfološka i kao sintaksičko-semantička kategorija, što znači [da] neizvorni govornici srpskog jezika u okviru jedne nastavne jedinice istovremeno usvajaju padežni nastavak i jedno od značenja određenog padeža, čime stiču znanje o tome u kojoj situaciji treba upotrebiti dati padež, odnosno razvijaju sposobnost stvaranja rečenica na srpskom jeziku" (Војновић 2007: 283). Оваква анализа треба да покаже да ли грешка постоји само у парадигматској морфеми или и у јединици која је у непосредној вези с именичком речи (у предлогу или обавезном детерминатору, будући да се падеж остварује као слободни или као везани падежни облик; Антонић 2005: 121), и уз коју се семантичку класу глагола употребљене именице јављају.

Посматра се облик акузатива погрешно употребљен у реченици, и уместо којег другог падежног облика, затим уместо којих његових функција или значења, да ли је грешка начињена и у избору предлога или не, ${ }^{2}$ на крају - и уз које глаголе. ${ }^{3}$ Падежи замењени акузативом распоређени су оним редом којим се наводе у традиционалним граматикама српског језика, а значења унутар једног падежа дата су према броју примера, опадајућим редом.

2. Акузатив уместо номинатива. - Номинатив, као основни падежни облик именица, уводи се на самом почетку почетног нижег нивоа учења српског језика, и то сва три његова типа: субјекатски, предикатски и апелативни. Акузатив, објекатски, уводи се нешто касније, у трећој лекцији истог нивоа, на његовој средини.

2.1. Замена субјекатског номинатива. - Падеж субјекта, номинатив, који се увек остварује у слободној форми, доследно је замењен истом таквом, слободном формом акузатива. Замене су најчешће уз копулативни глагол јесам/бити, јесам ('налазити се') и недостајати, а спорадичне уз: налазити се, волети, допадати се, имати ('поседовати'), изгледати, почињати, свиђати се, требати:

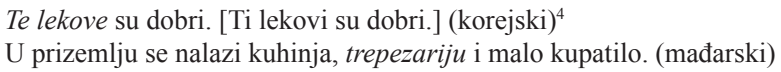

${ }^{1}$ Наставни комплет Научимо српски - Let's Learn Serbian 1 (уџбеник, радна свеска и ЦД с вежбама слушања, издање Центра и Филозофског факултета) чини окосницу наставног програма почетних курсева.

${ }^{2}$ Приступ падежима, класификација њихових функција и значења, па сходно томе и класификација грешака у њима у потпуности се теоријски заснива на опису падежног система српског језика датом у Антонић 2005.

${ }^{3}$ Осим у функцији глаголске допуне, у малобројним случајевима анализирана је и погрешна употреба акузатива уз придев у функцији семантичког језгра копулативног предиката, будући да је свега седам таквих примера.

${ }^{4}$ За разлику од основног текста, примери су исписани латиницом, као и у самим саставима студената - због тога што се у појединим речима мешају енглески и српски правопис, било је немогуће исписати их ћирилицом. У угластој загради, кад је то неопходно и да би се избегла двосмисленост, на основу ширег контекста реконструише се одговарајући правилан облик. У облој загради је наведен први језик студента. 
Међу наведеним глаголским лексемама пажњу привлачи неколико њих, и то начином на који су употребљене у реченичној конструкцији, начином на који су је оформиле. Глаголи недостајати, свиђати се, допадати се и треба$m и$ везују уз себе два субјекта: семантички субјекат у дативу (псеудоагенс) и граматички у номинативу (тј. семантички објекат), а конгруирају - наравно - с овим другим (Недостаје ми ПОРОДИЦА, на пример). У писаној језичкој продукцији страних студената, међутим, нађени су сасвим другачији примери:

Sviđam se njegovu uslugu. - I ja. (korejski)

Još uvek ja nedostajem $i h$. (engleski)

Код њих је псеудоагенс у номинативу, семантички објекат у акузативу без предлога, глагол (недостајати, свиђати се) опет конгруира с појмом у номинативу, само што је то овај пут падеж псеудоагенса ( Ми недостајемо ЊУ). Јасно је да је реченична конструкција потпуно супротна оној правилној и очекиваној, али је јасно и то да није настала случајно јер у целости одговара структури реченице коју граде прелазни глаголи српског језика ( Ја волим ЧОКОЛАДУ, на пример). То је она реченична структура коју студенти дуго уче, увежбавају и користе, и после које им је тешко да схвате и усвоје ову нову и потпуно обрнуту структуру. При том не треба искључити ни утицај енглеских еквивалената (to like, to miss) и њихових допуна (We miss уои, на пример).

Реченице с глаголима допадати се и требати застале су негде између правилне и неправилне конструкције: у њима је семантички субјекат остварен у правилном облику датива, док се семантички објекат (тј. граматички субјекат) јавља у падежу правог, граматичког објекта - акузативу (а не номинативу). У обе реченице глагол јесте употребљен правилно, у оном облику (у 3. лицу једнине) који би био конгруентан с именичким појмом у номинативу (да је номинатив остварен), али како су оба именичка појма у једнини - ми заправо и не знамо према којем је од њих студент управио глаголски облик:

$\mathrm{Ne}$ dopada mi se većinu. (korejski)

Neću treba mi kuhinju zato što restoran će biti ispod moja stana. (hindi)

До сада описане грешке забележене су уз глаголе који се уводе на почетним нивоима знања српског језика. Далеко већи број грешака, међутим, начињен је у реченичној конструкцији која није предвиђена за учење на овим нивоима - у егзистенцијалној персоналној реченици с глаголом имати ('постојати') у предикату. Као и трећина претходно описаних примера, и ове реченице (готово све) јављају се у оквиру описа куће и просторија у њој, јер управо ова тематска целина пружа велику могућност за њихову употребу.

Поред глагола имати у предикату и предметне појаве (чије се постојање утврђује) у акузативу (а не у номинативу), готово све реченице садрже још и спацијалну одредбу: 
а) у форми предлошког локатива, распоређеног најчешће испред предиката и акузатива, или иза њих, на крају реченице:

U mojem stan ima kupatilo, kuhinju, spavaću sobu i jedan krevet. (korejski)

Naravno ima zavesu na prozora. ${ }^{5}$ (korejski)

б) у форми предлошког генитива, распоређеног чешће испред предиката и акузатива него иза њих:

Takođe ima terasu pored prozora. (engleski)

в) у форми прилога, употребљеног чешће на почетку реченице него на њеном крају:

Ima stolicu tamo takođe. (engleski)

Како у свим овим примерима егзистенцијалне персоналне реченице имамо именицу која означава избројиву појаву у једнини, њен правилан падежни облик може бити само номинатив једнине, с којим се предикат слаже у лицу и броју (3. лице једнине: има). Облик генитива овде није могућ јер је он резервисан за множину избројиве појаве, као и за неизбројиву појаву ((Ha улици и) има људи, одн. (У кући) има струје, уп. Ивић 1981: 23 и Арсенијевић 1993: 66-67), и при том нема конгруенције између њега и предиката (егзистенцијална имперсонална реченица).

Због синкретизма акузатива и номинатива једнине мушког (с обележјем живо /-/) и средњег рода, одн. акузатива и генитива једнине мушког рода (с обележјем живо /+/), у овом корпусу таквих именица нема, овде се бележе само именице женског рода једнине (на - $a$ ), код којих је облик акузатива неупитан. Именице мушког рода множине, међутим, одликују се засебним наставком за облик акузатива, за разлику од женског и средњег рода множине, код којих је овај падеж синкретизован с номинативом. Тако се од множинских облика у акузативу бележе именице мушког рода (прозори, столови, хотели) и - мислим - под њиховим утицајем и у њиховој непосредној близини још и две женског и једна средњег рода (полище, планине, мора):

U poslednjoj sobi ima dve lampe pored zid, zavesa iza prozora, tri fotelje, dva kauča, akvarium za kornjače, police za knige, prozore, i stolove. (engleski)

Tamo je ima planine i mora i hotele. ${ }^{6}$ (korejski)

Као што је већ речено, егзистенцијална детерминација избројивих појмова у множини постиже се употребом глагола имати и именицом у генитиву

\footnotetext{
${ }^{5}$ Овде се ради о скривеној грешци (уп. Кордер $\left.{ }^{2} 1975 \mathrm{~b}: 166\right)$, јер без увида у шири контекст не може се закључити да је глагол неправилно употребљен. Наиме, дешава се да студент у једном истом саставу меша личну и безличну употребу глагола имати, па тако пише да он има нешто, да стан или соба има нешто, а понекад глагол користи и имперсонално. Због тога је у свим ситуацијма строго вођено рачуна о ширем контексту и о томе коју интерпретацију дозвољава - прву, другу или трећу.
}

${ }^{6}$ Ради се о само једној планини и једном мору, тако да је грешка остварена и у броју. 
множине (уп. Ивић 1981: 23 и Арсенијевић 1993: 66-67), a „množina u toj semantičkoj funkciji danas je nešto malo odstranjena iz književnog izražavanja" (Грицкат 1961: 77). Под множином овде И. Грицкат мисли на номинатив множине (не генитив), а онда и на множински облик глагола имати, који конгруира с њим (нпр. Имају две грчке легенде, сличне, једна дужа а друга краћа; Имају, дакле, и наслеђене беде као што постоје и наслеђене среће (преузето из Грицкат 1961: 77)). Али ни у једном од три наведена рада не дају се примери какве имамо у студентским саставима - да се у једној истој реченици, истим предикатом утврђује постојање и једнинских и множинских појмова, тј. да се у функцији субјекта у напоредном односу јављају именице различитог броја, као и паукалне синтагме. Примери у корпусу показују нам да су такви искази могући и да за њима постоји потреба. Поставља се питање како их третирати - као правилне или као неправилне? У овом другом случају - и како их исправити, којим средствима?

U poslednjoj sobi ima dve lampe pored zida, zavesa na prozoru, tri fotelje, dva kauča, akvarijum za kornjače, police za knjige, prozori, i stolovi.

Tamo [na ostrvu] ima planina, more i hoteli.

Na radnom stolu ima računar, knjige, novine, olovke, papiri, pisma, i sveska. ${ }^{7}$ (engleski)

Као што смо видели, множински облици именичког појма у номинативу и предиката мало су одстрањени из савременог језика, према томе - и кад бисмо их употребили - звучали би посве необично (Тамо имају планине; $\mathrm{Ha}$ радном столу имају књиге, новине, оловке...; У дневној соби имају две лампе ${ }^{8}$ ). Закључак који налазимо у Мразовић - Вукадиновић 1990: 678: „Ako je i rod i broj naporednih subjekata različit, onda se promenljivi oblici glagola i prideva upravljaju prema bližem" (уп. и Стевановић ${ }^{2} 1974:$ 125-126), даје нам за право да исти принцип применимо и на анализиране примере: да једнински облик глагола имати (и не само у студентским саставима него и код изворних говорника) употребимо у случајевима када му је ближа именица у једнини, одн. множински његов облик када му је ближа именица у множини или паукална синтагма.

У вези с детерминацијом избројивих појмова у множини треба споменути и то да се у неколико случајева студенти и јесу повели за чињеницом да говоре о постојању већег броја појединачних предмета, па су према таквим субјектима управили и глаголски облик (имају). Оно што су изворни говорници у свом књижевном језику одбацили, странци су видели као логично средство изражавања:

\footnotetext{
${ }^{7}$ Ова реченица је наведена само као илустрација, истакнути примери јесу у номинативу множине.

${ }^{8}$ Као и други глаголи уз паукалну синтагму (нпр. У дневној соби се налазе две лампе), тако би и глагол имати требало да буде у множини.
} 


\author{
U mojoj sobi imaju mali krevet, velik prozor, dva ormana, i klavir. ${ }^{9}$ (korejski) \\ U sestrinoj sobi imaju sto, stolicu, dve police za knjige, jedan orman, krevet i velik \\ prozor. (korejski)
}

Иако егзистенцијалне реченице - ни персоналне ни имперсоналне - студенти не уче на почетним нивоима, с њима су се могли срести у природном окружењу, у којем су дуго боравили. Окружени изворним говорницима свакодневно су могли слушати реченице као што су: Има (једна) продавница; Има сока; Има људи - које су кратке, па самим тим студентима звуче једноставно и привлачно, само што за странце почетнике нису нимало једноставне (и не само за странце, уп. „у колоквијалном језику значење 'постојати“ најчешће се изриче глаголом имати, а ту искрсавају својеврсни проблеми” (Ивић 1981: $23)$, при том М. Ивић мисли на изворне говорнике, пред којима искрсавају ти проблеми, не на стране студенте). С друге стране, студенти су месецима учили и користили персоналну реченицу с транзитивним глаголом имати и његовом карактеристичном објекатском допуном, у акузативу (нпр. Имам брата / сесmpy). Реченичне конструкције које налазимо у њиховој писаној продукцији, по свему судећи, настале су укрштањем елемената егзистенцијалне реченице и реченице с транзитивним глаголом имати у предикату - укрштањем предикатског облика има ('постоји') из прве реченичне конструкције и допуне транзитивног глагола имати ('поседовати') у форми беспредлошког акузатива - из друге. Треба поновити и то да су далеко бројнији примери погрешне употребе акузатива (уместо субјекатског номинатива) у егзистенцијалним реченицама него у свим осталим типовима реченица. Због свега наведеног, егзистенцијалне реченице су овде анализиране, и поред тога што се не уводе на почетним нивоима. У прилог закључку да транзитивно имати ('поседовати') утиче на појаву акузатива и у безличној реченици са егзистенцијалним имати ('постојати“) иде и чињеница да се у ранијим истраживањима, у оваквим реченицама, генитив уместо номинатива појављује три пута (Бабић 2017: 364), а локатив само једном (Бабић 2016: 705).

2. 2. Замена предикатског номинатива. - Беспредлошки акузатив доследно замењује и предикатски номинатив, углавном у функцији семантичког језгра копулативног предиката:

Moja dnevna soba je spavaču sobu, i sve se nalazi ovde. (portugalski)

По једном је замењен и номинатив с везником као уз семикопулативни глагол радити у идиоматизованој структури, одн. номинатив као допуна придеву у функцији семантичког језгра копулативног предиката:

Ona radi kao medicniska sestru na jedan universitet, u San Antonio. (engleski)

Crna kafa u Koreji nije isto kao tursku (srpsku) kafu. (korejski) облику.

${ }^{9}$ Све именице су мушког рода, па се не може тврдити да је начињена грешка у падежном 
2.3. Замена апелативног номинатива. - Појава акузатива забележена је и уместо номинатива у функцији апелатива, тј. основног облика именичке речи ван синтаксичке структуре:

(Račun molim. -) Cash ili cartiću? - cartiću. (portugalski)

3. Акузатив уместо генитива. - Погрешна употреба акузатива забележена је уместо шест типова генитива: спацијалног, субјекатског, каузалног, темпоралног, објекатског и партитивног. Од тога, два типа се уопште не уводе на почетним нивоима (субјекатски и каузални), док се остали уводе: спацијални (аблативност) пре објекатског акузатива, партитивни и темпорални (с предлозима пре, после) убрзо након њега (све на нивоу А1), објекатски пред крај нивоа A1, спацијални (посредна локализација) и темпорални (непосредна локализација) знатно касније, на нивоу А2.

3.1. Замена спацијалног (просторног) генитива. - Као што се спацијални генитив у српском језику остварује искључиво као везани падежни облик, тако се и акузатив употребљен уместо њега у продукцији студената појављује искључиво у предлошко-падежној структури - готово увек с прилошко-предлошким спојем или предлозима карактеристичним за ово значење генитива: десно од, испред, између, поред, преко. Више од половине забележених примера јавља се у опису куће и просторија у њој, од глаголских лексема бележе се јесам ('налазити се'), налазити се, имати ('постојати'), ићи, отићи и прелити:

Ispred sofu je sto. (korejski)

Sledeći dan smo preko Austriju odišli kući. (češki)

3.2. Замена субјекатског генитива. - Као што је већ споменуто, у егзистенцијалним реченицама, с глаголом имати ('постојати') у предикату, могућ је и генитив у функцији субјекта. Ради се о имперсоналној реченици и функцији семантичког субјекта - у једнини или множини, у зависности од тога да ли је појам чија се егзистенција утврђује избројив (у генитиву множине) или неизбројив (у генитиву једнине). Трансфер допуне транзитивног глагола имати, који је постојао код субјекатског номинатива, постоји и код субјекатског генитива, па се и уместо њега у студентским радовима јављају облици акузатива:

U mojoj porodici nema mršave ljude. [nema mršavih ljudi] (španski)

U kolaču ima čokoladu. [ima čokolade] (korejski)

Слободни генитив редовно је замењен слободним акузативом, који је распоређен иза глагола, онако како би био распоређен и генитив да је употребљен. У поређењу с грешкама у субјекатском номинативу, може се рећи да је овде појава акузатива ретка. Ни једна ни друга врста егзистенцијалних реченица (ни персонална ни имперсонална) не учи се на почетним нивоима, а како грађа показује - студенти су далеко чешће писали о избројивим појавама него о неизбројивим. 
3.3. Замена предлошког каузалног (узрочног) генитива остварена је предлошким акузативом:

Ako ti hoćeš da ideš tamo za novac, nemoj da ideš, ja ću zaraditi još. (korejski)

Ono se srušilo zbog zlonamernu paljevinu pre godine. (korejski)

Акузативни предлог за јавља се уместо генитивних предлога због и од.

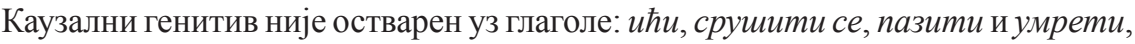
од којих се последња два не уче на почетним нивоима, па од студената не треба ни очекивати да знају којим падежним обликом их допуњавамо.

3.4. Замена темпоралног (временског) генитива остварена је два пута, у оба случаја уз генитивни предлог после:

Posle kafu ako mogu, doručkujem nešto, pa operem sudovi. (mađarski)

3.5. Замена објекатског генитива остварена је само једном:

Imamo vreme samo u prazniku koj je u februaru, znači od 16. do 22. februara. (poljski)

Настанак ове грешке своје узроке може имати у томе што студенти уче да транзитивни глагол имати допуњавамо првенствено обликом акузатива (ретки су примери генитива уз њега: имам новца и сл.), као и у томе што именица време представља изузетак од тог правила - уз глагол имати њу користимо у генитивном облику.

3.6. Замена партитивног генитива. Грешка слична претходној забележена је и у раду једног немачког студента:

Ali nema mnoge vreme jer radi mnogo. [mnogo vremena] (nemački)

С тим што је овде немогуће знати да ли је желео да употреби прилог (много) или придев (многи, $-a,-o)$, да ли је онда ово партитивни или објекатски генитив. У оба случаја - и прилог много и транзитивно немати (као и имати) захтевају генитивни облик именице време. Како придев многи, - $a$, -о није ни могућ уз ову именицу, многе се сматра прилогом, а време грешком оствареном уз квантификатор, тј. у партитивном генитиву.

4. Акузатив уместо датива. - Неправилна употреба акузатива забележена је уместо објекатског датива (датива индиректног објекта и експликативног датива), затим субјекатског, спацијалног и предикатског датива. Изузев појединих глаголских лексема, сви ови типови датива уводе се на почетним нивоима знања језика.

\section{1. Замена објекатског датива.}

4.1.1. Датив индиректног објекта. - Датив у функцији индиректног објекта замењен је акузативом уз прелазне глаголе који у стандардном језику добијају две објекатске допуне - директни објекат (у форми слободног акузатива или објекатске клаузе) и индиректни објекат (у форми слободног дати- 
ва): дати, казати, препоручити / препоручивати, предавати, рећи, кувати, нудити, певати и приказати. Неки од ових глагола или се уопште не уче на почетним нивоима (нудити) или се не уче с дативном допуном (предавати, приказивати):

Preporučio sam moje prijatelje Srbiju. (korejski)

Kuvati ću tebe za ručak. [Kuvaću ti ručak.] (korejski)

Замена слободног датива у највећем броју случајева остварена је слободним акузативом. У мањем броју примера употребљен је акузатив с предлогом за - што своје оправдање може имати у чињеници да и ова предлошко-падежна конструкција уз прелазне глаголе, као и датив, има значење намене и функцију индиректног објекта (нпр. дати нешто за некога). Но и поред тога што оба падежна облика могу бити у функцији индиректног објекта, ипак се не ради о синонимији, они међусобно нису заменљиви нити допуњавају исте глаголске лексеме: ${ }^{10}$

Često on peva za mene. [Često mi on peva.] (korejski)

4.1.2. Експликативни датив. - Слободни акузатив употребљен је и уместо слободног датива као семантичке допуне непрелазним глаголима помоћu, досађивати и глаголу који се не учи на почетним нивоима: веровати:

I onda ja često pomognem nju. [I onda joj ja često pomažem.] (korejski)

У готово свим примерима у погрешном облику остварена је лична заменица, и то углавном у пуном облику: мене, њу, нас и је. И само једна именица.

4.2. Замена субјекатског датива. - Акузатив с предлогом за јавља се и као замена слободног датива у функцији семантичког субјекта уз глагол требати, и придеве симпатичан, интересантан, који су у функцији семантичког језгра копулативног предиката:

Problem je, da za mene treba veoma mnogo vremena da kažem nešto. (nemački)

Беспредлошки акузатив бележи се уз глаголе стајати и свиђати се:

Karirnin odeća je dobro stoja. [Karirana odeća im dobro stoji.] (korejski)

Ne sviđa $m e$ se Dana i Stephanie zato što one nikad ne razgovoraju sa mene. (engleski)

4.3. Замена спацијалног (просторног) директивног датива (или датива правца). - Појава акузатива уместо слободног датива у функцији спацијалног детерминатора сасвим је спорадична. Као локализатор-циљ, уз глаголе стићи и $u \hbar u$, два пута је употребљена лексема кућа, једном с предлогом $y$ и једном као слободна падежна форма:

${ }^{10} \mathrm{y}$ вези с овим, неопходно је напоменути да је у ранијим истраживањима забележен занемарљив број грешака у употреби индиректног датива - локативом и генитивом замењен је само по једном (Бабић 2016: 713; Бабић 2017: 367). Разлог томе може бити управо заједничка функција акузатива и датива - функција објекта, првенствено индиректног објекта. 
Kad stignem $u$ kuću večeram, tuširam i četujem sa drugovama. (mađarski) Posle podne idem kuću i čitam sport novine. (španski)

Велики број примера употребе акузатива уместо датива могао би имати неколико својих узрока. Први је временски размак у којем се две форме уводе - акузатив се уводи средином почетног нижег нивоа, а датив, као последњи падеж, пред крај почетног вишег нивоа. Самим тим, студенти имају много више времена да увежбају акузатив и да се навикну на његове форме. Затим, ради се о два падежа која испуњавају функцију објекта - акузатив функцију директног и индиректног објекта, датив само индиректног. Та чињеница ствара околности погодне за замену објекатских форми (нарочито форми индиректног објекта, иако оне у српском језику нису синонимне). Додатни проблем представљају личне заменице - које овде преовладавају, а чије су форме страним студентима иначе тешке. И на крају, многи од ових примера настали су пре него што је у наставни процес уведен датив и глаголи уз које се он користи.

Пошто је датив изједначен с локативом (који се учи на самом почетку нивоа A1), не би се могло рећи да су студентима тешке његове форме - јер ако су научили форме локатива, онда морају знати и форме датива. Пре би се дало закључити да су им тешке реченичне структуре у којима се датив остварује, тј. употреба глагола и њихових допуна и детерминатора у облику датива.

5. Акузатив уместо инструментала у писменим саставима страних студената јавља се ретко, по свему судећи случајно, па - самим тим - не указује ни на какве правилности. Забележен је укупно три пута, уместо два типа која се уче на почетним нивоима - уместо социјативног и квалификативног инструментала. У свим реченицама грешка је направљена и у инструменталном предлогу $c$ :

Šta želite na pljeskavicu? [sa pljeskavicom] (portugalski)

Danas imamo jaje od šunku i sirova i paradajz. [jaja sa šunkom] (engleski)

6. Акузатив уместо локатива. - Употреба акузатива забележена је уместо седам типова локатива: спацијалног, објекатског, квалификативног, експликативног, темпоралног, каузалног и локатива основа (или критеријума). Од тога, само се каузални локатив не уводи на почетним нивоима знања језика.

6.1. Замена спацијалног (просторног) локатива. - Акузатив се јавља уместо локатива у функцији спацијалног детерминатора - како уз глаголе уз које је локализатор обавезан (налазити се негде, остати негде, живети негде) тако и уз оне уз које је факултативан (имати нешто (негде), плесати (негде)). Пошто се готово свака предикација може одредити с обзиром на околност типа простор, овде се бележе глаголи који припадају различитим семантичким класама. Као и локатив, који се у српском језику обавезно реализује као предлошко-падежна конструкција, и акузатив употребљен уместо њега у највећем броју случајева остварен је у истом структурном лику, и то: a) с одговарајућим предлогом $y$ или на, и б) с погрешним предлогом. 
а) Замена локатива предлошким акузативом с одговарајућим предлогом y или на најчешћа је уз копулативно јесам/бити (уз именски предикат, или у саставу прилошког предиката), егзистенцијално имати ('постојати'), налазити се, живети, прелазно имати, затим радити, шетати се, добити, плесати и сретати се:

On je najniži u porodicu. (engleski)

U spavaću sobu se nalazi samo krevet. (korejski)

Prvo, sam se šetao $u$ centar i video sam mnogo crkava, džamija i jednu sinagogu takođe. (engleski)

Oni se šetaju $u$ šumu zato što sviđa mi se priroda. (korejski)

б) Замена локатива акузативом с погрешним предлогом:

- y уместо по:

Ona želi da dolazi u Novom Sadu, u Srbiji. I putuje $u$ Evropu. ${ }^{11}$ (korejski)

- на уместо по:

Kad ne idemo nigde idem da serfujem na internet. (mađarski)

- y уместо на:

Mi smo šetali $u$ tvrđavu i u centru. (korejski)

- на уместо $y$ :

Mi idemo zajedno da treniramo na teretanu. (španski)

Овде су међусобно замењени предлози $y, н а$ и по, који се комбинују и са акузативом и са локативом, а њихов избор у стандардном српском језику зависи од семантике именице и/или глагола у предикату. Само једном употребљен је предлог који није ни акузативни ни локативни, већ генитивни - предлог од уместо на:

I levo od i desno od kauć su stolove i od stolove je lampe. (engleski)

Како се у овом делу корпуса јављају глаголи кретања шетати се и $n y-$ товати, и како је речено да је облик акузатива уз њих погрешно употребљен, треба указати на неколико специфичности у вези с овим лексемама. Уводећи циљни акузатив (средином почетног вишег нивоа), студенте учимо да га користимо уз глаголе кретања (тј. глаголе с обележјем динамичност /+/) како бисмо њиме исказали циљ, тј. место завршетка тога кретања, за разлику од локатива, којим означавамо место вршења радње и који користимо уз тзв. глаголе мировања (тј. глаголе с обележјем динамичност /-/; уп. Ивић 1957: 150-151). Проблем настаје када студенти ово правило (овако поједностављено и прилагођено њиховом нивоу знања српског језика) аутоматски примене и на два наведена глагола. Наиме, циљни акузатив уз глагол щетати се, иако

\footnotetext{
${ }^{11}$ Без ширег контекста, реченица И путује у Европу била би граматички сасвим правилна.
} 
он има обележје динамичност / + /, није могућ - посве су необичне реченице: Шетам се у парк / на тврђаву. ${ }^{12}$ Његова допуна може бити спацијални локатив с предлогом $y /$ на или, још чешће, с предлогом по (Шетам се $y / n o$ парку; Шетам се на/по тврђави), или - овом другом сличан - просекутивни инструментал, што овде није тема (Шетам се парком). Што се тиче глагола путовати, циљни акузатив јесте једна од његових могућих допуна (Путујем y Грчку), али свакако није једина. И он, као и шетати се, може бити детерминисан спацијалним локативом с предлогом $n o$, а ова предлошко-падежна конструкција уз значење места вршења радње садржи и специфично обележје простирања по површини локализатора, или још прецизније: „уз глаголе кретања показује да је кретањем у различитим смеровима захваћена цела површина локализатора" (Антонић 2005: 283-284; нпр. Шетам се по парку / по тврђави; Путујем по Европи). ${ }^{13}$

С обзиром на то да су обе локативне конструкције (с предлогом $y / н a$, одн. no) могуће уз глагол шетати се, појава предлога $y / н a$ у забележеним примерима није сматрана погрешном, ${ }^{14}$ иако би у појединим случајевима примеренији био предлог по, нарочито кад за локативном конструкцијом следи набрајање свега што је виђено током шетње - набрајање објеката обухваћених локализатором (Прво сам се шетао ПО ЦЕНТРУ и видео сам много иркава, иамија и једну синагогу). За остале примере могло би се рећи да у првом плану није простирање по површини локализатора него генеричко (уопштено) значење места, те да је стога сасвим прихватљив предлог у уз локатив (Они се шетају У ШУМИ; Често се шета У ЦЕНТРАЛ ПАРКУ; Ми смо шетали НА ТВРБАВИ). Обе локативне конструкције (с предлогом $y /$ н и по) студентима су познате - прву уче на почетном нижем нивоу, другу средином почетног вишег нивоа, с тим што се на ову другу навикавају много теже, јер за њено увежбавање имају мање времена и могућности. И то је основни разлог што су у анализираним примерима изабрали предлог $y$, а не по.

6.2. Замена објекатског локатива. - У малобројним примерима и објекатски локатив замењен је акузативом. Уз два прелазна глагола остварена је форма карактеристична за функцију директног објекта - беспредлошки акузатив:

\footnotetext{
${ }^{12}$ Глагол шетати се, према РМС, значи 'ходати, ићи лаганим кораком ради одмора и разоноде; ићи, ходати тамо-амо“. Тако дефинисано кретање нема посебан циљ који се жели достићи, на којем се радња жели завршити, оно је само себи циљ. Оно се започиње с намером да се заврши тамо где је и започето, на истој тачки с које се пошло. Колико је необичан акузатив као детерминатор глагола шетати се толико је необично и питање с прилогом за смер кретања: Куд (волиш да) се шеташ? Обично се пита за место кретања Где (волиш да) се шеташ?

${ }^{13} \mathrm{O}$ значењима предлога по у конструкцији с локативом (и с другим падежима) в. и Ивић $1951-1952$.

${ }^{14}$ УП. и „Značenje prostiranja po izvjesnoj površini, odnosno vršenja glagolske radnje u raznim pravcima ne traži uvijek bezuslovno po $+l$, pa se zato javlja Beli medvedi su plivali ... u bazenu" (Батистић 1972: 33).
} 


\author{
Kad učim Srbiju na fakultetu u Južnoj Koreji... [kad sam učio o Srbiji] (korejski) \\ (korejski) \\ Kada stižem u Koreju, želim da priča život u Srbiji. [želim da pričam o životu u Srbiji]
}

Прелазни глаголи учити и причати - истина - у српском језику могу бити допуњени беспредлошким акузативом у функцији директног објекта (нпр. учити математику, причати бајку), али не у овом контексту. Овде је потребна друга врста допуне - локатив с предлогом о у функцији индиректног објекта.

6.3. Замена квалификативног локатива акузативом остварена је два пута:

Gotovo sve vreme smo pričali srpski. [na srpskom] (poljski)

Dve žene i dva čoveka su razgovaraju na pare. [u parovima] (engleski)

6.4. У корпусу су по једном нађене и:

а) Замена експликативног локатива, тј. локатива у функцији семантичке допуне уз глагол уживати, који је допуњен беспредлошким акузативом, могуће - по узору на енглески еквивалент: enjoy something:

Oko dva sata smo samo sedeli pored reke i uživali smo pogled. (poljski)

б) Замена темпоралног (временског) локатива:

Imamo posebnu cenu u sezonu i posle sezoni. (poljski)

в) Замена каузалног (узрочног) локатива, уз придев захвалан у функцији семантичког језгра копулативног предиката, при чему је дошло и до замене предлога - за уместо на:

Zahvalan sam za moje porodice i ne treba da živim ih bez. (engleski)

г) Замена локатива основа или критеријума, уз придев познат у функцији семантичког језгра копулативног предиката, праћена погрешним избором предлога (за уместо по), што опет свој узрок може имати у језику посреднику, тј. у допуни енглеског еквивалента: famous for:

Sukatra je poznat za ovo retko drvo. (arapski)

Спацијални локатив се у наставном процесу уводи готово на самом почетку нивоа A1 (у 2. лекцији, убрзо након номинатива). Форме акузатива се уводе средином нивоа А1 (у 3. лекцији, објекатски акузатив) и средином нивоа A2 (пред крај 2. лекције, спацијални или циљни акузатив). Ако се употреба локатива уместо акузатива може објаснити као унутарјезичка интерференција, тј. утицај раније ученог и чешће коришћеног на оно што се касније учи (Бабић 2016: 723-724), поставља се питање како и зашто долази до употребе акузатива уместо локатива? Да ли се ради о утицају често коришћеног на оно што се учило раније? Јер транзитивни глаголи и њихова објекатска допуна јесу веома фреквентни. (Сличну појаву видели смо и у замени номинатива акузативом, в. поглавље 2.) Или се ради о томе да две спацијалне допуне 
међусобно интерферирају? Тешко је дати јасан одговор, али врло је вероватно да је у питању ово друго.

7. Закључак. - У писаној продукцији страних студената забележена су укупно 223 примера употребе акузатива у синтаксичким функцијама које су захтевале неки други падежни облик. Најчешћа је његова појава уместо номинатива (85) и локатива (72), знатно мања уместо датива (39) и генитива (24), и сасвим спорадична уместо инструментала (3). Детаљнији преглед сваког замењеног падежа показује да су најбројније грешке у оном његовом значењу које се може сматрати основним на почетним нивоима: у субјекатском номинативу (74/85), спацијалном локативу (63/72) и објекатском дативу (31/39). Код генитива најчешће грешке су подељене између спацијалног и субјекатског типа - по осам примера за сваки.

Ако знамо да је унутарјезичка интерференција утицај раније ученог (и чешће коришћеног) на оно што се учи касније, онда је необична чињеница да су студенти акузативом најчешће замењивали оне падежне облике који у наставном процесу претходе акузативу, а то су субјекатски номинатив и спацијални локатив. У првој категорији проблем су, заправо, направиле егзистенцијалне реченице, које студенти не уче, али их ипак користе, не знајући правила њиховог структурирања. Показало се да једна структура, одн. једно значење глагола имати ('поседовати') и њему одговарајућа форма допуне (акузатив) утичу на појаву те исте форме уз исти глагол али другачијег значења (егзистенцијално, 'постојати') и другачије валенције (глагол који уз себе везује само номинатив). Другим речима, показало се да учена и чешће коришћена структура утиче на форму која се усваја а не учи - што такође представља унутарјезичку интерференцију. У другој категорији - врло вероватно - ради се о узајамној интерференцији двеју спацијалних допуна (спацијалног акузатива и спацијалног локатива), која настаје услед неразликовања две семантичке класе глагола (а онда и њихових допуна) - тзв. глагола кретања и глагола мировања. Редослед учења (али и учесталост употребе акузатива) као одлучујући фактор може се видети једино код замењених облика датива, јер се он уводи након акузатива.

Упоредимо ли структурни лик оствареног акузатива и неоствареног падежа, видимо да се у највећем броју случајева први подудара с другим, тј. да је акузатив употребљен у оном структурном лику у којем је дати падеж требало да буде употребљен (205/223). При том је избор предлога углавном правилан (што значи да одговара функцији или значењу неоствареног падежа), сасвим спорадично изабран је погрешан предлог (19/205).

До сада изнете чињенице представљају својеврсне доказе унутарјезичке интерференције у писаној језичкој продукцији страних студената, и дају основа да се њихове грешке сматрају унутарјезичким. Не све, наравно, али 
оне најбројније свакако да - замена субјекатског номинатива, спацијалног локатива и датива (176/223).

Укупан број грешака (223), број студената који су их начинили (54) и број њихових првих језика (12) такође указује на то да се највећи број грешака може довести у везу с циљним језиком. При том се нипошто не искључује могућност да су неке од ових грешака настале и под утицајем првог језика студента. Или чак и под утицајем језика посредника (енглеског).

\section{ЛИТЕРАТУРА}

Антонић 2005: И. Антонић, Синтакса и семантика падежа, у: П. Пипер и др. Синтакса савременога српског језика: проста реченица (ред. Милка Ивић), Београд: Институт за српски језик САНУ, Београдска књига - Нови Сад: Матица српска, 119-300.

Арсенијевић 1993: N. Arsenijević, O posesivnim i egzistencijalnim rečenicama sa glagolom imati i njihovim mađarskim ekvivalentima, Нови Сад: Зборник Матице српске за филологију и лингвистику, XXXVI/2, $61-69$.

Бабић 2016: B. Babić, Greške u upotrebi oblika lokativa na početnim nivoima učenja srpskog jezika kao stranog, Зборник у част Љиљани Суботић Теме језикословне у србистици кроз дијахронију и синхронију, Нови Сад: Филозофски факултет, 703-726.

Бабић 2017: B. Babić, Greške u upotrebi oblika genitiva na početnim nivoima učenja srpskog jezika kao stranog, Језици и културе у времену и nростору VI, Нови Сад: Филозофски факултет, 363-377.

Батистић 1972: T. Batistić, Lokativ u savremenom srpskohrvatskom književnom jeziku, Beograd: Institut za srpskohrvatski jezik (Biblioteka Južnoslovenskog filologa, Nova serija, knjiga 3).

Бјелаковић, Војновић 52014: I. Bjelaković, J. Vojnović, Научимо српски-Let's learn Serbian 1, Novi Sad: Filozofski fakultet.

Бугарски 1996: R. Bugarski, Greške u jeziku, u: Lingvistika o čoveku, Beograd: Čigoja štampa, XX vek, 156-163.

Бурзан 1984: M. Burzan, Interferencija u predikatu srpskohrvatske rečenice u jeziku učenika mađarske narodnosti, Novi Sad : Filozofski fakultet, Institut za južnoslovenske jezike.

Војновић 2007: J. Vojnović, Usvajanje padežnog sistema u nastavi srpskog jezika kao stranog (početni nivo), Savremene tendencije u nastavi jezika $i$ 
književnosti, Beograd: Ministarstvo za nauku i zaštitu životne sredine, Filološki fakultet Univerziteta, 281-289.

Грицкат 1961: I. Grickat, Razvoj značenja glagola imati, Radovi (Radovi Odjeljenja istorijsko-filoloških nauka Naučnog društva NR BiH), knj. XVIII, knj. 6, 67-81.

Елис ${ }^{4}$ 1996: R. Ellis, The Study of Second Language Acquisition, Oxford: Oxford University Press.

Ивић 1951-1952: М. Ивић, О предлогу по у српскохрватском језику, Београд: Јужнословенски филолог, XIX/1-4, 173-212.

Ивић 1957: М. Ивић, Једно поглавље из граматике нашег модерног језика - систем месних падежа, Нови Сад: Годишњак Филозофског факултета у Новом Саду, књига II, 145-157.

Ивић 1981: М. Ивић, Српскохрватски глаголски облици за исказивање појава које постоје у садашњости, Београд: Јужнословенски филолог, XXXVII, 13-24.

Кордер 21975a: S.P. Corder, The Significance of Learners' Errors, Error Analysis - Perspectives on Second Language Acquisition, London: Longman, 19-27.

Кордер ${ }^{2}$ 1975б: S.P. Corder, Idiosyncratic Dialects and Error Analysis, Error Analysis - Perspectives on Second Language Acquisition, London: Longman, 158-171.

Мразовић, Вукадиновић 1990: P. Mrazović, Z. Vukadinović, Gramatika srpskohrvatskog jezika za strance, Sremski Karlovci: Izdavačka knjižarnica Zorana Stojanovića - Novi Sad: Dobra vest.

Ричардс ${ }^{2}$ 1975: J. C. Richards, A Non-Contrastive Approach to Error Analysis, Error Analysis - Perspectives on Second Language Acquisition, London: Longman, 172-188.

PMC 2007: Речник српскога језика, Нови Сад: Матица српска.

Стевановић ${ }^{2}$ 1974: М. Стевановић, Савремени српскохрватски језик (Граматички системи и књижевнојезичка норма). II Синтакса, Београд: Научна књига. 


\section{INTRALINGUISTIC ERRORS IN USING ACCUSATIVE FORMS AT THE BEGINNING LEVELS OF LEARNING SERBIAN AS A FOREIGN LANGUAGE}

\section{Summary}

In the paper, there has been carried out a morphosyntactic analysis of using accusative forms of nouns (with predication) instead of other case forms, which has been done on the corpus formed by excerption of errors from student essays (the levels A1 and A2). The aims of the analysis are the following: the identification of errors, their systematization according to types, the excerption and description of intralinguistic errors and their cause, quantification and statistical processing, presenting results of analysing errors according to their types and according to students' native language.

The analysis has shown that accusative forms have been used 223 times instead of other case forms, most frequently instead of the nominative case (85 instances) and the locative case (72), far less frequently instead of the dative case (39) and the genitive case (24), and rarely instead of the instrumental case (3). Out of these, at least 176 errors can be explained as intralinguistic ones and these refer to the replacement of subject nominative forms, spatial locative forms and dative forms. Representatives of 12 languages have made errors in the use of the accusative case.

Key words: Serbian as a foreign language, morphology, syntax, cases, accusative, error analysis.

Biljana M. Babić 